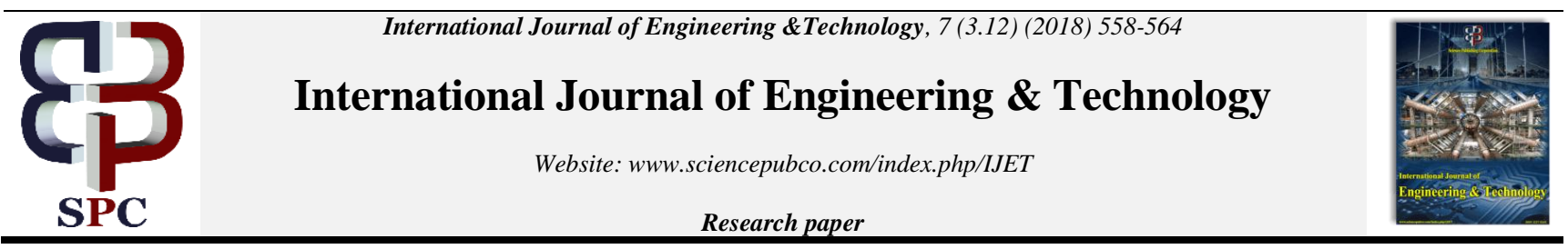

\title{
Determination of Watershed Characteristics and Curve Number (CN) for Ponnaniyaru Dam Catchment Area
}

\author{
Selvakumar $\mathbf{R}^{1}$, Nasir $\mathbf{N}^{2}$, Suribabu $\mathbf{C} \mathbf{R}^{3^{*}}$ \\ ${ }^{1}$ Assistant Professor, ${ }^{2}$ Research Scholar, ${ }^{3}$ Professor, \\ ${ }^{1,2,3}$ School of Civil Engineering, SASTRA Deemed University, Thanjavur-613 401, Tamil Nadu, India. \\ *Corresponding author E-mail: ${ }^{3}$ suribabu@ civil.sastra.edu
}

\begin{abstract}
In SCS-CN method, curve number is significant parameter in estimating runoff from the catchment of the reservoir or inflow to the reservoir. As this curve number is function of several parameters like hydrological soil group, LULC, land treatment, hydrologic conditions and $\mathrm{AMC}$, the selection of $\mathrm{CN}$ for prediction of inflow to the lake or reservoir is considered as a crucial in the hydrological studies. LULC, micro-watershed, drainage density, and catchment slope are obtained using spatial analysis and also SCS Curve Number value for Ponnaniyaru dam catchment area is derived from the LULC data. Further, CN value is evaluated from actual rainfall data and runoff volume collected at the reservoir. The study reveals the significant variation of $\mathrm{CN}$ value among each event. The present case study highlights the sensitiveness of $\mathrm{CN}$ value in the computation of runoff from the watershed. Keywords: Curve number, LULC, AMC, drainage density.
\end{abstract}

\section{Introduction}

The term Runoff means, draining off of precipitated water in a catchment after surface and sub-surface losses. Prediction on runoff is a vital component in most watershed based planning, design and operation projects. Models on runoff estimation are broadly classified as lumped, distributed and semi-distributed models. Amongst, the Soil Conservation Service Curve Number (SCS-CN) method has proven an easy and trustworthy method (Stuebe and Johnston 1990; Mishra and Singh 1999; Michel et al 2005; Sahu et al 2007). Especially at micro watershed level land use and land cover, soil, slope, rainfall, drainage and lithology are considered as controlling parameters (Prasad et al 1993; Yusof et al 2000; Cosh et al 2004). The spatial information on these can be precisely obtained from remotely sensed satellite data (Ponce and Hawkins 1996; Mishra et al 2005). Meanwhile geographic information system (GIS) enables to handle and analyze the above voluminous spatial data (Cheng et al 2006; De Winnaar et al 2007). The remotely sensed data, soil data and GIS software helps to find out the curve number value for the catchment interested for estimation of runoff. Nevertheless, the runoff obtained through the calculation does not match with actual data. This happens due to inaccurate evaluation of variation of input data that persists at the field level. In such a situation, it is general practice to evaluate the model parameters from known output data of model. In the present study, Curve Number and other morphological parameters for Ponnaniyaru dam catchment area are obtained using spatial analysis.

The Alaviduthi Sub Watershed of Koralayar watershed falling in southern side of Karur district, Tamil Nadu, India comprises the study area, engulfed by remnants of Eastern Ghats with circular shaped structure with Perumalmalai in the north and Semmalai in the south (Figure.1). The Ponnaniyaru dam is nestled in the gorge between the hills with an aerial extent of 83 sq. km. The area receives an annual rainfall of $930 \mathrm{~mm}$, with maximum precipitation during northeast monsoon. The climate is semi-arid with hot from March to May, the temperature varies from 26 to $38^{\circ}$ C. The dam supports ayacut in Mugavanurpanchayat, Maniyarampatti, Periyaanaikarapatti and Manpaththai blocks of Tiruchirappalli district. Rain water harvested in the monsoon forms chief source of water for the dam. Even though region receives substantial annual rainfall, it is has been categorized under overexploited block (District Groundwater Brochure, 2008). 


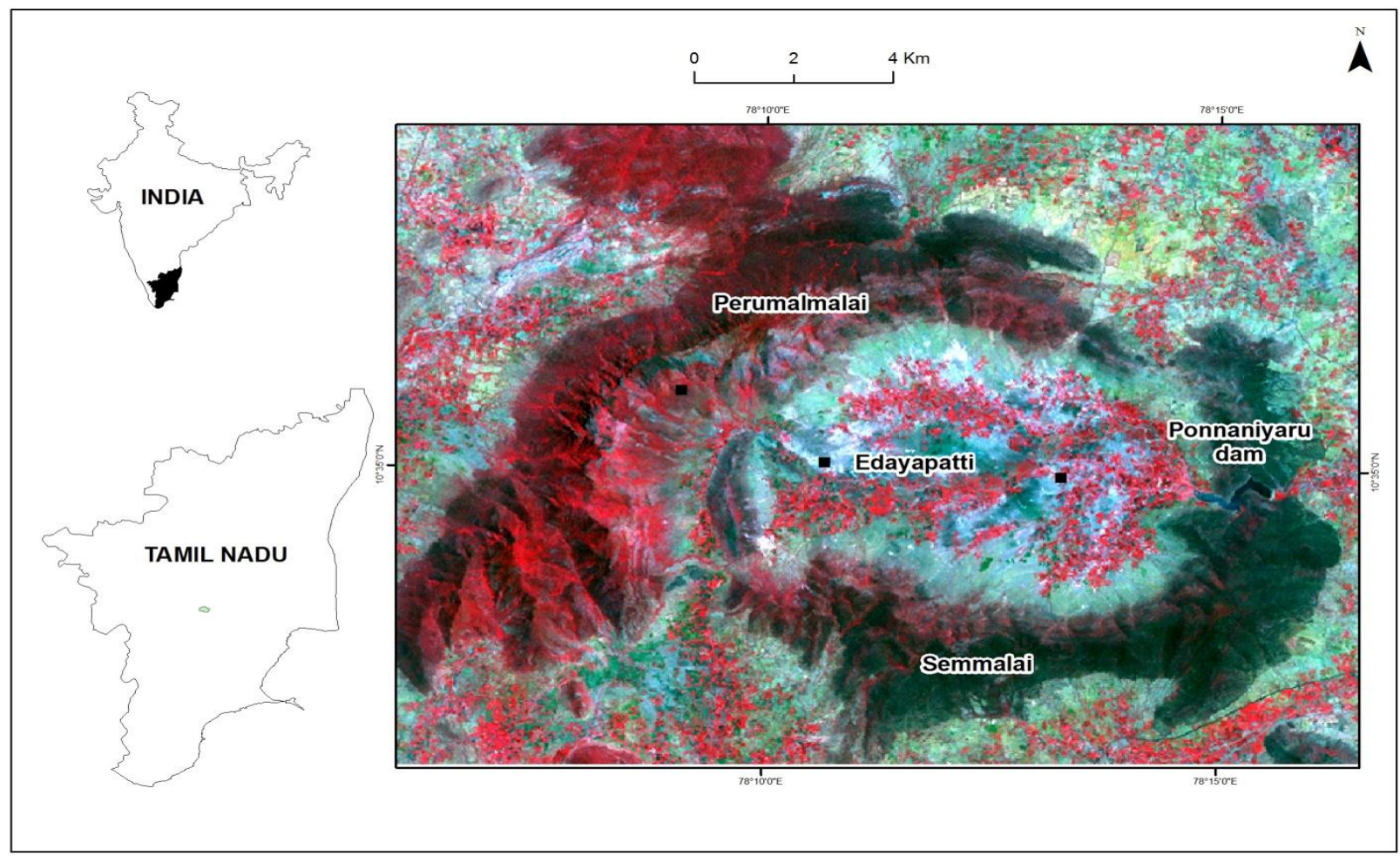

Fig.1: Landsat Satellite image showing study Area

\section{Materials and Methods}

Geomatics technology is gaining attention in recent decades, particularly in runoff modeling (Ravishankar and Mohan 2005; De Winnar et al 2007). Using Survey of India (SOI) topographic sheet, thematic layers like drainage, road, settlements, and so on were prepared. Then using Landsat satellite image, obtained from USGS website, the land use and land cover (LULC) map was prepared. Subsequently using the satellite image, soil map collected from state Public Works Department, Tamil Nadu and the drainage map derived from SOI topographic sheets were updated. The slope map of the study was generated using Shuttle Radar Topographic Mission (SRTM) data of $30 \mathrm{~m}$ spatial resolution. The derived thematic maps were converted into a spatial layer using ArcGIS software.

\section{SCS-CN Method}

SCS-CN method is an easy and trustworthy method being accepted in many countries for estimating the runoff. The method relies on the following.

Water balance equation:

$$
\text { Proportional equality : } \quad P=I_{a}+F_{c}+Q
$$

Hypothesis 1: Compare the ratio between surface runoff ' $Q$ ' and total rainfall ' $\mathrm{P}$ ' with ratio of infiltration ' $\mathrm{F}_{\mathrm{c}}$ ' and maximum retention ' $\mathrm{S}$ '.

$$
\text { Hypothesis : } \quad \frac{Q}{\left(P-I_{a}\right)}=\frac{F_{c}}{S}
$$

Hypothesis 2: Relates initial abstraction ' $\mathrm{I}_{\mathrm{a}}$ ' and the maximum retention.

\section{I - S hypothesis:}

$$
\mathrm{I}_{\mathrm{a}}=\lambda \mathrm{S}
$$

Where, $\mathrm{P}$ - total rainfall; $\mathrm{I}_{\mathrm{a}}$ - initial abstraction; $\mathrm{F}_{\mathrm{c}}$ - cumulative infiltration excluding $I_{a} ; Q$ - direct runoff depth; $S$-potential maximum retention or infiltration, and $\lambda$ - regional parameter dependent on geologic and climatic factors $(0.1<\lambda<0.3)$.
Resolving the above

$$
\begin{aligned}
& Q=\frac{\left(P-I_{a}\right)^{2}}{\left(P-I_{a}+S\right)} \\
& Q=\frac{(P-\lambda S)^{2}}{(P+(\lambda-1) S)}
\end{aligned}
$$

The relation between ' $\mathrm{a}$ ' and ' $\mathrm{S}$ ' was established using rainfall and runoff data and same is given as ' $\mathrm{I}_{\mathrm{a}}=0.2 \mathrm{~S}$ '.

The final form of equation after substituting $\lambda=0.2$ as follows

$$
Q=\frac{(P-0.2 S)^{2}}{(P+0.8 S)}
$$

The value of ' $\mathrm{S}$ ' is determined by relating it to $\mathrm{CN}$ as follows

$$
S=\left(\frac{25400}{C N}\right)-254
$$

The value of curve number is estimated based on the prevailing LULC, soil and Antecedent Moisture Condition(AMC) of the watershed.

\section{Drainage Network and Micro-Watershed Delineation}

Using SOI topographic sheet (58J/2), drainage map was prepared and subsequently updated using satellite imagery (Figure. 2). From the analysis, Seventeen micro-watersheds are identified and delineated with drainage network within it. 

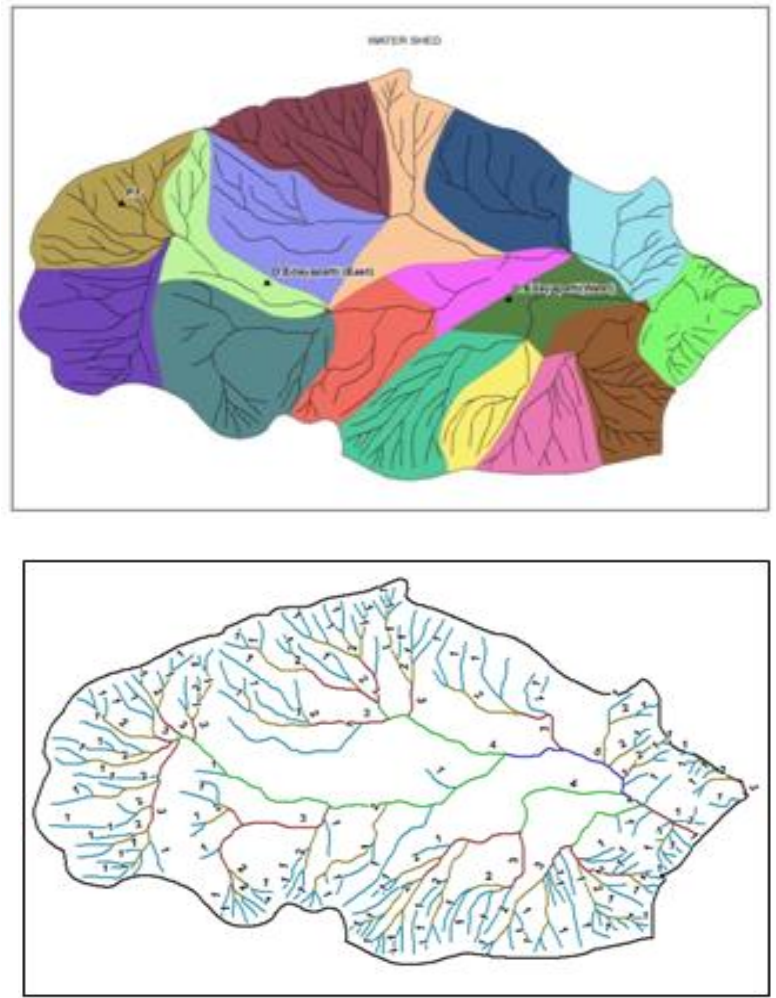

Fig .2: Map showing drainage network and microwatersheds
Run-off variability within a basin was controlled by basin geomorphology, especially the drainage network (Strahler's 1964). Drainage density is the total length of drainage per unit area (Horton 1932). Accordingly, using ArcGIS software, drainage map was integrated with micro-watershed map and thereby, length of drainages in each watershed is derived. By summing their lengths, total length of drainage in each watershed is derived and further by dividing it with their respective watershed area, drainage density in each micro-watershed is calculated and presented in the Table 1 .

\section{Land Use and Land Cover}

Curve number $(\mathrm{CN})$ is determined based on the LULC pattern. Landsat ETM satellite data (2001) was radiometrically corrected and subsequently, using unsupervised classification technique in ENVI software, image data was classified and updated through information collected from Watershed and Soil Atlas published by Government of Tamil Nadu. Further, refinement was done by field visit to the watersheds. Thus, the final LULC was prepared and the same shows 12 categories (Figure.3). Though the catchment area consists of all categories of LULC, the buildup area and water bodies are found to be minimal. There are few villages within the catchment area which contributes the buildup area and water body seen in the study area is the water spread area of the reservoir. Majority of catchment appears as scrub forest, land with and without scrub. Table 4 exhibits the details on area covered by different LULC of the catchment.

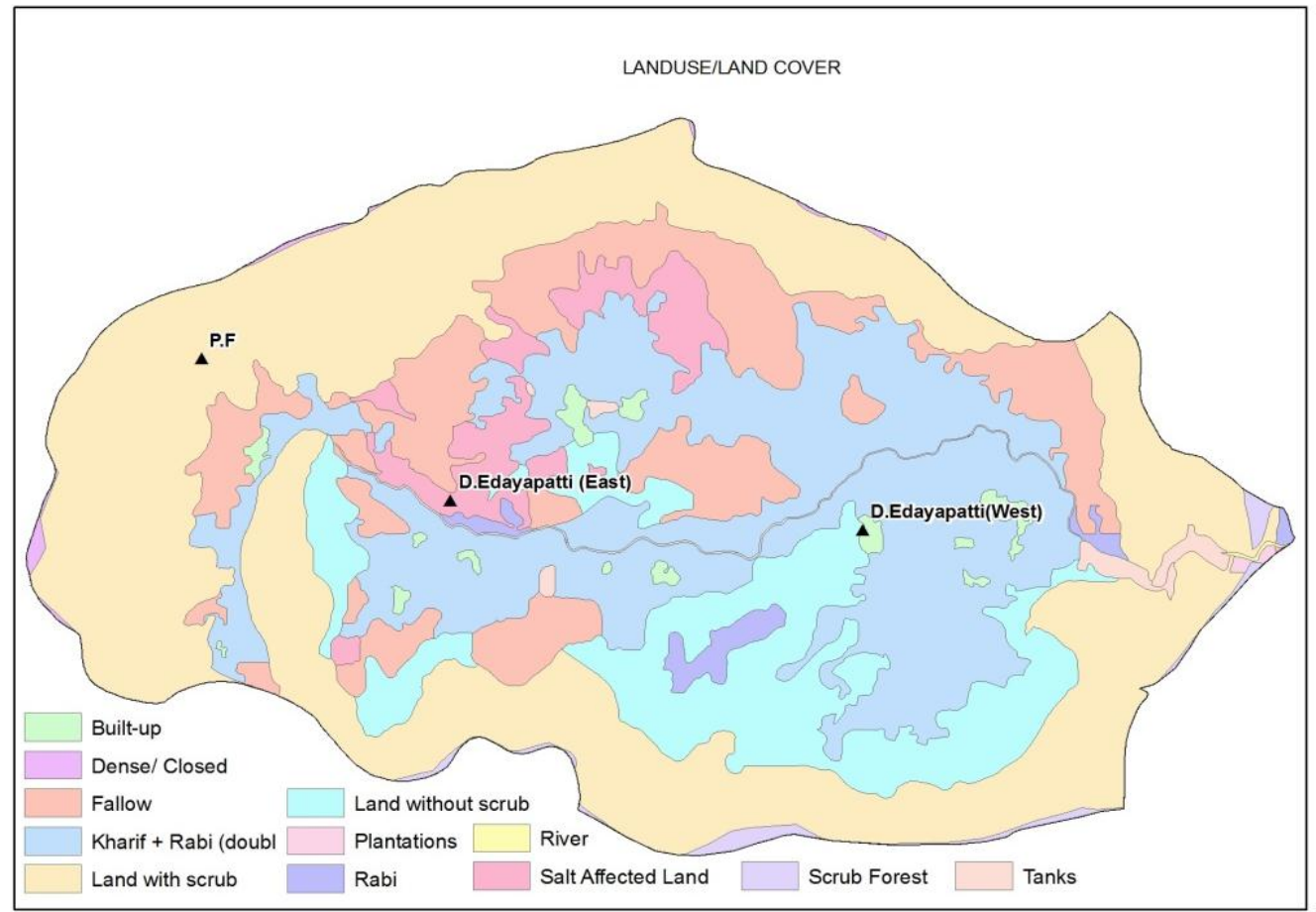

Fig. 3: Showing Land use and Land Cover

\section{Determination of Slope}

Runoff is generally influenced by the prevailing slope. Using Shuttle Radar Topographic Mission (SRTM) data with 3 arc seconds resolution, slope map was prepared. The SRTM data was calibrated using Ground Control Points (GCPs) collected from topographic sheet and subsequently, slope map was generated using surface analyst tool in ArcGIS software. The deduced slope ranges from 1 to $15 \%$ (Figure.4). 


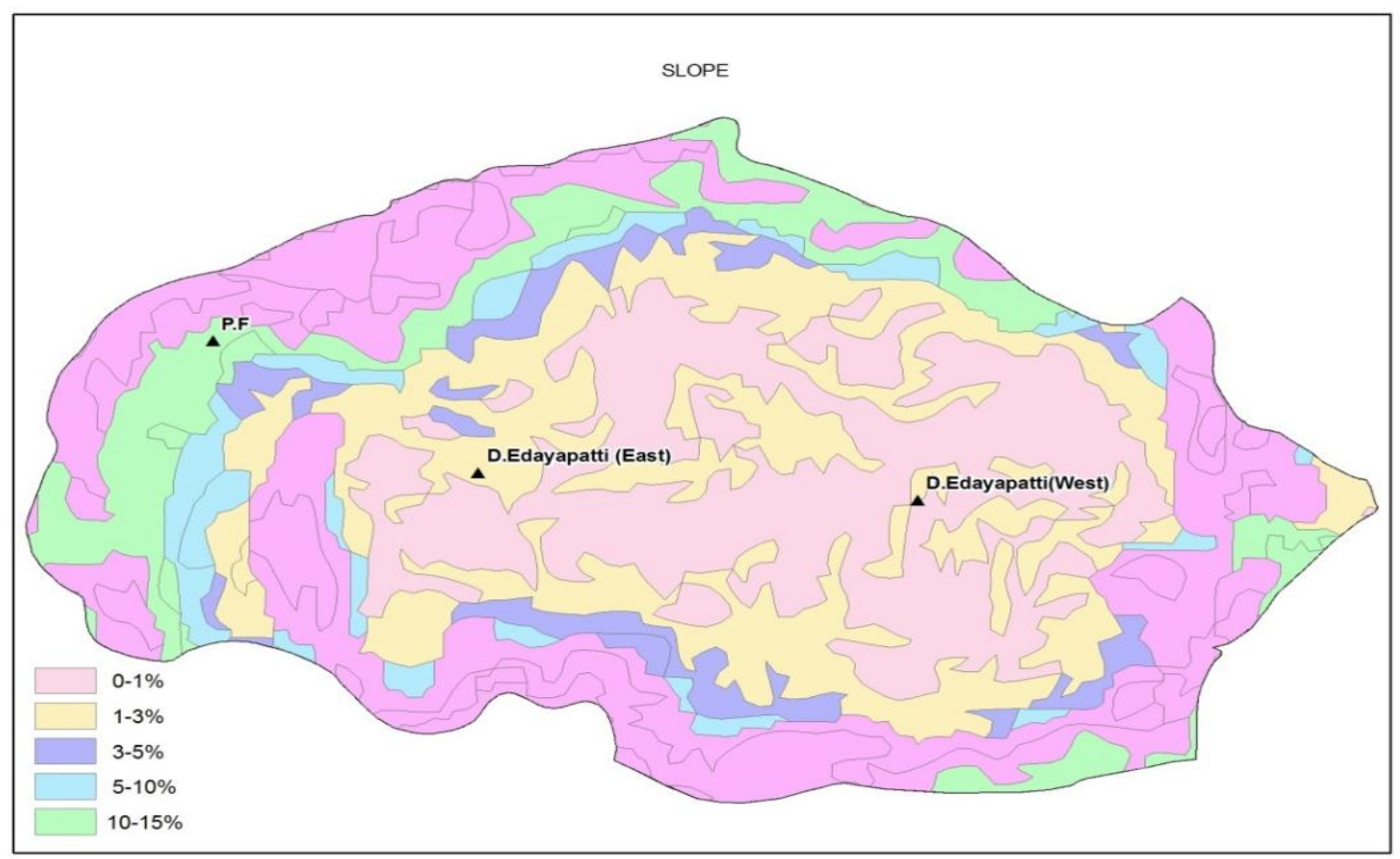

Fig. 4: Showing the slope of the study area

\section{Results and Discussion}

Watershed exhibits a dendritic drainage pattern. Table 1 presents the drainage density of seventeen sub-watersheds of the catchment. The minimum of $0.98 \mathrm{~km}^{-1}$ and maximum $3.45 \mathrm{~km}^{-1}$ are obtained for entire watershed. This maximum value of drainage density indicates that the reservoir catchment area fall in the category of low drainage density. A low drainage density catchment gives a longer period of surface runoff and more loss of rainfall (Yildiz 2004). This catchment area possesses highly permeable sub-soil and moderate drainage texture. The catchment possesses five stream order in which stream order 1 and 2 are dominating in the total stream length. The stream frequency of the catchment is derived as 4.368 which denote the low stream frequency catchment area. Table 3 present the geomorpological parameter of the catchment area. Shape of the catchment can signify the speed with which the runoff reaches an outlet. The shape factor suggests that the sub-basin is a square type. Further, the form factor values indicate that the sub-basin is elongated type rather a circular basin. Generally, the form factor greater than 0.78 , is designated perfectly as a circular basin. The present catchment area form factor falls below this value and that indicates the existence of certain degree of elongation. The circularity ratio of 0.677 of the catchment denotes that the basin possesses circular shape. While referring directly to the Figure.1, the shape of the basin appears as circular by excluding the hill engulfing the nearly plain area. When the engulfing hill is account with nearly plain area, the elongation could be understandable. The circular type catchment offers uniform infiltration and the excess water takes long time to reach the dam site. However, steep basin slope can accelerate movement of runoff water to the catchment outlet. The slope of the catchment various from 0 to 15 $\%$ and amongst 0 to $5 \%$ found to be dominant than above $5 \%$ to $10 \%$. The area with the slope range of $5 \%$ to $10 \%$ comes under hill area and other area has gentle slope towards the dam site. The land use and land cover of the study area comprises 12 categories (Figure.3). Though the catchment area consists of all categories of LULC, the buildup area and water bodies are found to be minimal. There are few villages within the catchment area which contributes the buildup area and water body seen in the study area is the water spread area of the reservoir. Majority of catchment appears as scrub forest, land with and without scrub. Table 2 provides the land use and land cover details with assigned $\mathrm{CN}$ value.

The $\mathrm{CN}$ value for each land use is selected from Runoff curve numbers for hydrologic soil cover complex correspond to watershed condition II (Average antecedent moisture condition $(A M C)$ for $I_{a}=0.2 S$. The weighted average of value is obtained for complete catchment area as 66.78 . From the available rainfall data and inflow resulted to such events to the reservoir from the catchment are collected from Public Work Department (PWD) of Ponnaniyaru reservoir division. Rainfall-runoff relationships for the catchment at the event scale were investigated using SCS-CN method to determine the $\mathrm{CN}$ value for the catchment area from 1998 to 2013. Amongst rainfall events with more than $20 \mathrm{~mm}$ precipitation is considered and corresponding volume of flow collected in the reservoir was clearly identified from PWD $\log$ book. Single event and consecutive rainfall event data are separated. From inflow data, the volume of water collected in the reservoir for each event is calculated and presented the same in the Table 5 and 6 . Taking $\lambda$ as 0.2 , the $\mathrm{CN}$ value for each event is calculated and presented in the Table 5 and 6 . The calculation CN for each is carried out by taking initial value obtained through land use classifications i.e. 66.78. The $\mathrm{CN}$ value is adjusted by trial and error method to minimize the percentage deviation from actual value. It can be observed from the result that different values are obtained each and every rainfall event for both single and consecutive events. The maximum, minimum and average $\mathrm{CN}$ value for single rainfall event is found as 72.2, 34.1, and 61.23 respectively with standard deviation of 9.84. In case of consecutive events, the corresponding values are 73.05, 30.2 and 53.51 respectively with standard deviation of 14.79 . The deviation of estimated value from actual value varies within $\pm 1 \%$. It is clear from the study that no rigid value for $\mathrm{CN}$ can be adopted for prediction of runoff from the catchment. Further, it is found from the analysis that $\mathrm{CN}$ is highly sensitive to the estimation of runoff. Small change in the $\mathrm{CN}$ value can lead to large deviation from the actual value. Hence, accurate evaluation of $\mathrm{CN}$ value is essential for prediction of runoff from the catchment. It is known that curve number is function of hydrological soil group, LULC, land treatment, hydrologic conditions and AMC. But, it is found from the study that for same site and same period of year, the $\mathrm{CN}$ value varies significantly. Such variation might be due to duration of rainfall, intensity of rainfall and morphological behavior of the catchment which is normally not quantified in the SCS curve method. The $\mathrm{CN}$ value derived from single event is found to be 
significantly higher than the consecutive day event. Such low value of $\mathrm{CN}$ would be result of the over estimate of initial abstraction value adopted in the SCS-CN method. Further, intensity of rainfall and actual duration of rainfall are not accounted in the SCS-CN method which results variation of $\mathrm{CN}$ value between the events. For entire catchment, the distribution of rainfall is considered as uniform since rainfall data is available from rainfall station located at the dam site. Accounting the actual distribution of rainfall over the catchment can further help to more accurate evaluation of the $\mathrm{CN}$ value for the catchment. The effect of systematic and random errors could not be neglected in such analysis.

\section{Conclusion}

Ponnaniyaru reservoir catchment area is a moderate and erratic rainfall region. The catchment does not have any perennial source of water. As, the catchment area is circumstanced by the hill, the entire rainwater collected in the catchment moves to the dam site after meeting its initial losses. Based on geomorpological parameters of the catchment area, it is identified as low drainage density and stream frequency catchment area. Seventeen subwatersheds are identified by using satellite imagery and Geological survey map. Six prime types of land uses are noted in the catchment area and its weighted $\mathrm{CN}$ number is estimated as 66.78. From the recorded rainfall data and runoff volume, the $\mathrm{CN}$ value is derived for each event independently and it shows the significant variation. From the analysis, it is found that $\mathrm{CN}$ value is highly sensitive variable in the prediction of runoff. Small change in its value creates large variation between actual and predicted runoff volumes. Large voluminous data on rainfall and runoff with categorizing and grouping these data based on duration, intensity, season and geomorphologic parameter certainly help to evaluate more accurate Curve Number value for the entire catchment area to predict the inflow to such a reservoir in general.

\section{References}

[1] Cheng, Q., Koa, C., Yuana, Y., Gea, Y. and Zhanga, S. (2006). GIS modeling for predicting river runoff volume in ungauged drainages in the Greater Toronto Area, Canada. Computers \& Geosciences. 32, 1108-1119.

[2] Cosh, M. H., Jackson, T. J., Bindlish, R. and Prueger, J. H. (2004). Watershed scale temporal and spatial stability of soil moisture and its role in validating satellite estimates. Remote Sensing of Environment. 92, 427-435.

[3] De Winnaar, G., Jewitt, G.P. and Wand Horan, M. (2007). GISbased approach for identifying potential runoff harvesting sites in the Thukela River basin, South Africa. Physics and Chemistry of the Earth. 32, 1058-1067.

[4] District Groundwater Brochure (2008). Technical Report Series, District Groundwater Brochure Karur District, Tamil Nadu, Government of India, Ministry of Water Resources, Central Ground Water Board.

[5] Horton, R.E. (1932). Drainage basin characteristics. Transactions American Geophysical Union. 13, 350-361.

[6] Michel, C., Andréassian,V. and Perrin, C. (2005). Soil conservation service curve number method: How to mend a wrong soil moisture accounting procedure? Water Resources Research, doi:10.1029/2004WR003191

[7] Mishra, S. K., Jain, M.K., Pandey, R.P. and Singh,V.P. (2005) Catchment area based evaluation of the AMC-dependent SCS-CNinspired rainfall-runoff models. Hydrological Processes, 19(14) 2701-2718.

[8] Mishra, S. K. and Singh, V.P. (1999). Another look at the SCS-CN method. Journal of Hydrologic Engineering, 4(3), 257-264.

[9] Osman Yildiz (2004). An Investigation of the Effect of Drainage Density on Hydrologic Response. Turkish Journal of Engineering and Environmental Science, 28, 85 - 94.

[10] Ponce, V. M. and Hawkins, R. H. (1996), Runoff curve number: Has it reached maturity? Journal of Hydrologic Engineering, 1(1), 11-19.

[11] Prasad, K.S.S., Gopi, S. and Rao, R.S. (1993). Watershed prioritization using remote sensing techniques - A case study of the Mahabubnagar District, Andhra Pradesh, India, International Journal of Remote Sensing. 14, 3239-3247.

[12] Ravishankar, M.N. and Mohan, G. (2005). A GIS based hydrogeomorphic approach for identification of site-specific artificial-recharge techniques in the Deccan Volcanic Province. Journal of Earth System Science, 114(5), 505-514.

[13] Sahu, R.K., Mishra, S.K., Eldho, T.I. and Jain, M. K. (2007). An advanced soil moisture accounting procedure for SCS curve number method; Hydrological Processes, 21, 2872-2881.

[14] SCS (1993). National engineering handbook, Section 4: Hydrology, chapter 4, soil conservation service, USDA, Washington, D.C.

[15] Strahler, A.N. (1964). Quantitative geomorphology of drainage basins and channel networks. In: Chow VT, editor. Handbook of Applied Hydrology. New York: McGraw-Hill. 439-476.

[16] Stuebe, M. M. and Johnston, D. M. (1990). Runoff volume estimation using GIS technique. Water Resource Bulletin. 26(4), 611-620.

[17] Yusof, K.W., Serwan, M. and Baban, J. (2000). Identifying optimum sites for locating reservoirs employing remotely sensed data and geographical information systems. Proceedings of $21 \mathrm{st}$ Asian Conference on Remote Sensing, December 4-8, 2000, Taipei, Taiwan.

Table 1: Watershed wise Drainage Density

\begin{tabular}{|c|c|c|c|}
\hline \multicolumn{2}{|c|}{ Watershed } & \multirow{2}{*}{$\begin{array}{c}\text { Length of Drainage } \\
\text { in each watershed }(\mathbf{m})\end{array}$} & \multirow{2}{*}{ Drainage density $\left(\mathbf{m}^{-\mathbf{1}}\right)$} \\
\hline Number & Area (sq.m) & 18985.39 & 0.00307 \\
\hline 1 & 6189733.90 & 17908.97 & 0.00335 \\
\hline 2 & 5343741.86 & 9103.70 & 0.00227 \\
\hline 3 & 4010195.54 & 16690.93 & 0.00205 \\
\hline 4 & 8136581.27 & 13306.13 & 0.00199 \\
\hline 5 & 6671187.85 & 19603.06 & 0.00339 \\
\hline 6 & 5787095.34 & 11786.27 & 0.00258 \\
\hline 7 & 4574172.04 & 11735.16 & 0.00219 \\
\hline 8 & 5365321.78 & 10898.09 & 0.00175 \\
\hline 1 & 6217733.24 & 3728.34 & 0.00129 \\
\hline 10 & 2899712.09 & 20630.91 & 0.00382 \\
\hline 12 & 5404871.63 & 11174.54 & 0.00267 \\
\hline 13 & 4192825.85 & 2937.15 & 0.00098 \\
\hline 14 & 2987345.55 & 8447.63 & 0.00311 \\
\hline 15 & 2715450.41 & 11978.27 & 0.00317 \\
\hline 16 & 3781138.33 & 15817.11 & 0.00325 \\
\hline
\end{tabular}

Table 2: Stream details of Watershed

\begin{tabular}{|c|c|c|}
\hline Stream Order & Stream count & Length (m) \\
\hline 1 & 187 & 123876.8942 \\
\hline
\end{tabular}




\begin{tabular}{|l|c|c|}
\hline 2 & 104 & 48484.5337 \\
\hline 3 & 43 & 22308.6810 \\
\hline 4 & 19 & 18053.4919 \\
\hline 5 & 9 & 3561.8134 \\
\hline
\end{tabular}

Table 3:Ponnaniyaru Watershed geomorphologic parameters

\begin{tabular}{|c|c|c|}
\hline Sl. No. & Parameter & Value \\
\hline 01 & Catchment area & $82.8749 \mathrm{~km}^{2}$ \\
\hline 02 & Perimeter & $39.24 \mathrm{~km}^{-1}$ \\
\hline 03 & Drainage density & $2.625 \mathrm{~km}^{-1}$ \\
\hline 04 & Watershed length & $14.625 \mathrm{~km}$ \\
\hline 05 & Shape factor & 2.581 \\
\hline 06 & Form factor & 0.59 \\
\hline 07 & Compactness co-efficient & 1.216 \\
\hline 08 & Elongation ratio & 0.702 \\
\hline 09 & Circulatory ratio & 0.677 \\
\hline 10 & Stream frequency & 4.368 \\
\hline 11 & Watershed highest stream order & 5 \\
\hline 12 & Cumulative stream length & $1326.28 \mathrm{~km}$ \\
\hline 13 & Fineness ratio & 33.80 \\
\hline 14 & Drainage texture & 11.47 \\
\hline
\end{tabular}

Table 4: Land use and land cover details of the reservoir catchment area

\begin{tabular}{|c|c|}
\hline Sl. No & \\
\hline 1 & \\
\hline 2 & \\
\hline 3 & \\
\hline 4 & \\
\hline 5 & \\
\hline 6 &
\end{tabular}

Land use type
Built up
Crop Land
Fallow Land
Land with scrub
Land without scrub
Water Bodies
Total catchment Area

\begin{tabular}{|c|c|}
$\begin{array}{c}\text { Area } \\
\text { (sq.m) }\end{array}$ & CN Number \\
\hline 807729.09 & 90 \\
\hline 24070914.60 & 72 \\
\hline 10681039.95 & 74 \\
\hline 35349422.08 & 60 \\
\hline 11259964.40 & 66 \\
\hline 830677.62 & 100 \\
\hline 82999747.74 & 66.78 \\
\hline
\end{tabular}

\begin{tabular}{|c|c|c|c|c|c|c|}
\hline $\begin{array}{l}\text { Sl. } \\
\text { No. }\end{array}$ & Date of rainfall & $\begin{array}{c}\text { Daily } \\
\text { Rainfall } \\
(\mathbf{m m})\end{array}$ & $\begin{array}{l}\text { Actual Runoff volume } \\
\text { recorded at reservoir }\left(\mathrm{m}^{3}\right)\end{array}$ & $\begin{array}{l}\text { Derived CN } \\
\text { value }\end{array}$ & $\begin{array}{l}\text { Estimated Runoff } \\
\text { volume }\left(\mathbf{m}^{3}\right)\end{array}$ & $\begin{array}{c}\text { Percentage } \\
\text { deviation from } \\
\text { actual }\end{array}$ \\
\hline 1 & 15-08-1998 & 32.4 & 53680.32 & 68.5 & 53892.80 & -0.3958 \\
\hline 2 & 05-09-1998 & 46 & 28088.64 & 57.35 & 28458.73 & -1.3176 \\
\hline 3 & $07-10-1998$ & 30.2 & 8916.48 & 65.85 & 9097.53 & -2.0305 \\
\hline 4 & $10-10-1998$ & 53.4 & 30412.8 & 53.5 & 30853.22 & -1.4481 \\
\hline 5 & $28-10-1998$ & 39.8 & 107274.2 & 66.12 & 109351.07 & -1.9360 \\
\hline 6 & 06-05-1999 & 49.8 & 54190.8 & 57.04 & 54489.01 & -0.5516 \\
\hline 7 & 15-05-1999 & 30.2 & 34560 & 68.80 & 34804.98 & $\begin{array}{l}-0.7089 \\
\end{array}$ \\
\hline 8 & 17-08-1999 & 35.2 & 29358.72 & 64.5 & 29590.97 & $\begin{array}{l}-0.7911 \\
\end{array}$ \\
\hline 9 & 19-08-1999 & 31.8 & 16295.04 & 65.64 & 16294.49 & 0.0033 \\
\hline 10 & $24-04-2000$ & 32 & 26904.96 & 66.63 & 27125.34 & 0.815 \\
\hline 11 & $26-09-2000$ & 30 & 29358.72 & 68.5 & $\begin{array}{l}29261.48 \\
\end{array}$ & -0.9567 \\
\hline 12 & $02-10-2000$ & 37 & 117434.9 & 68.5 & 116325 & -0.7982 \\
\hline 13 & $30-11-2000$ & 32 & 14679.36 & 65.3 & 14760.44 & -1.1923 \\
\hline 14 & $02-01-2001$ & 90 & 73396.8 & 41.45 & 73262.22 & 0.1833 \\
\hline 15 & $14-09-2001$ & 32 & 61683.45 & 69.25 & 61162.56 & 1.008 \\
\hline 16 & $12-10-2001$ & 24 & 12225.6 & 71.65 & 12245.35 & 1.1025 \\
\hline 17 & $26-10-2001$ & 85 & 831401.3 & 57.91 & 824493.4 & 0.8308 \\
\hline 18 & $14-11-2001$ & 23.6 & 12225.6 & 72.03 & 12266.18 & 0.6096 \\
\hline 19 & $02-02-2002$ & 66 & 53818.56 & 49.1 & 53371.28 & 0.8311 \\
\hline 20 & $19-10-2002$ & 31 & 4890.24 & 64.4 & 4913.37 & -0.8300 \\
\hline 21 & $20-10-2002$ & 66 & 9789.12 & 45.85 & 9777.96 & 0.114 \\
\hline 22 & $22-10-2002$ & 22 & 4869.68 & 72.2 & 4890.24 & $\begin{array}{l}-0.7961 \\
\end{array}$ \\
\hline 23 & $06-11-2002$ & 40 & 75841.92 & 64.35 & 76476.5 & -0.8367 \\
\hline 24 & $24-11-2005$ & 219 & 1972326 & 34.1 & 1980915.13 & -0.4355 \\
\hline 25 & $01-05-2010$ & 80 & 22014.72 & 41.96 & 21772.93 & 1.098 \\
\hline 26 & 04-11-2011 & 50.2 & 357203.5 & 67.1 & 359513.3 & 0.7964 \\
\hline 27 & $07-11-2011$ & 52 & 172990.1 & 61 & 173870.87 & -0.5092 \\
\hline 28 & $10-10-2012$ & 45 & 144374 & 64.2 & 145732 & -0.9408 \\
\hline 29 & $18-02-2013$ & 31 & 4890.24 & 64.4 & 4930.83 & -0.830 \\
\hline 30 & $25-04-2013$ & 38 & 7344 & 59.85 & 7320.9 & -0.3144 \\
\hline
\end{tabular}

Table 6: Derived CN value from consecutive days rainfall and runoff volume

\begin{tabular}{|c|c|c|c|c|c|c|c|}
\hline $\begin{array}{c}\text { Sl. } \\
\text { No. }\end{array}$ & Date of rainfall & $\begin{array}{c}\text { Period } \\
(\text { Day(s)) }\end{array}$ & $\begin{array}{c}\text { Daily } \\
\text { Rainfall } \\
(\mathbf{m m})\end{array}$ & $\begin{array}{c}\text { Actual Runoff volume } \\
\text { recorded at reservoir } \\
\left(\mathbf{m}^{\mathbf{3}}\right)\end{array}$ & $\begin{array}{c}\text { Derived CN } \\
\text { value }\end{array}$ & $\begin{array}{c}\text { Estimated Runoff } \\
\text { volume }\left(\mathbf{m}^{\mathbf{3}}\right)\end{array}$ & $\begin{array}{c}\text { Percentage } \\
\text { deviation from } \\
\text { actual }\end{array}$ \\
\hline 1 & $\begin{array}{c}01-08-2000 \text { to } \\
04-08-2000\end{array}$ & Four & 56.4 & 31803.84 & 52.1 & 32076.96 & -0.8586 \\
\hline
\end{tabular}




\begin{tabular}{|c|c|c|c|c|c|c|c|}
\hline 2 & $\begin{array}{c}09-08-2000 \& \\
10-08-2000\end{array}$ & Two & 81 & 98625.6 & 45.3 & 98284.15 & 0.3462 \\
\hline 3 & $\begin{array}{c}20-08-2000 \& \\
21-08-2000\end{array}$ & Two & 41 & 26904.96 & 60.3 & 26725.48 & -0.7318 \\
\hline 5 & $\begin{array}{c}27-12-2000 \& \\
28-12-2000\end{array}$ & Two & 101.8 & 92957.76 & 38.8 & 92309.97 & 0.6968 \\
\hline 6 & $\begin{array}{c}11-04-2001 \& \\
12-04-2001\end{array}$ & Two & 27 & 14679.4 & 69.35 & 14579.64 & -0.1416 \\
\hline 7 & $\begin{array}{c}16-11-2002 \& \\
17-10-2002\end{array}$ & Two & 62 & 178597.4 & 55.9 & 179449.51 & -0.4771 \\
\hline 8 & $\begin{array}{c}24-10-2002 \text { to } \\
26-10-2002\end{array}$ & Three & 35 & 66018.24 & 67.32 & 66394.81 & -0.5704 \\
\hline 9 & $\begin{array}{c}21-08-2006 \& \\
22-08-2006\end{array}$ & Two & 27.6 & 32849.28 & 70.8 & 32932.77 & -0.2542 \\
\hline 10 & $\begin{array}{c}24-05-2007 \& \\
25-05-2007\end{array}$ & Two & 26.5 & 48902.2 & 73.05 & 49240.6 & -0.692 \\
\hline 12 & $\begin{array}{c}21-11-2008 \text { to } \\
30-11-2008\end{array}$ & Ten & 179.8 & 494190.72 & 30.2 & 497434.42 & -0.6564 \\
\hline
\end{tabular}

